\title{
Development of a web-based worksheet with a project-based learning model assisted by GeoGebra
}

\author{
Effie Efrida Muchlis 1, 2, a, *, Nanang Priatna ${ }^{2, b}$, Jarnawi Afgani Dahlan ${ }^{2, c}$ \\ ${ }^{1}$ Mathematics Education Department, Universitas Bengkulu \\ Jl. W.R. Supratman, Kandang Limun, Muara Bangkahulu, Bengkulu 38371, Indonesia \\ ${ }^{2}$ Mathematics Education Department, Universitas Pendidikan Indonesia \\ J1. Dr. Setiabudhi No. 229, Bandung, Jawa Barat, 40154, Indonesia \\ E-mail: ${ }^{a}$ effie_efrida@unib.ac.id, ${ }^{b}$ nanang_priatna@upi.edu, ${ }^{c}$ jarnawi@upi.edu \\ * Corresponding Author
}

\section{ARTICLE INFO}

\section{Article history}

Received: 29 May 2021

Revised: 4 June 2021

Accepted: 15 June 2021

\section{Keywords}

Web-based worksheet, project-based learning, GeoGebra, plane geometry course, research and development

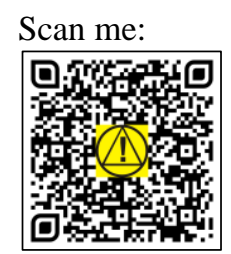

\section{ABSTRACT}

Previous studies on the use of GeoGebra in mathematics learning were more focused on implementation and effectiveness in learning outcomes. However, not many studies focus on providing opportunities to students to explore GeoGebra to find concepts in plane geometry through developing an application. Therefore, this research and development applied a 4D model to produce a webbased worksheet using project-based learning (PjBL) assisted by GeoGebra that was valid, practical, and effective in the plane geometry course. The web-based worksheet intended to facilitate students to be independent, creative, and able to find the concepts in the plane geometry course through exploration activities using GeoGebra. The results of the data analysis revealed that this research and development produced a web-based worksheet using PjBL assisted by GeoGebra that was valid, practical, and effective. The validity of the web-based student worksheet was shown from the validation results explaining that the worksheet was good in terms of content, construction, and language. The practicality of the worksheet was shown from the results of practitioner assessments and student questionnaires, showing that the web-based worksheet was easy to use and attractive. The effectiveness of the worksheet was shown from the formative assessment results with the interpretation that the use of the webbased worksheet could help students understand the content of plane geometry well.

This is an open access article under the CC-BY-SA license.

How to Cite: Muchlis, E. E., Priatna, N., \& Dahlan, J. A. (2021). Development of a web-based worksheet with a project-based learning model assisted by GeoGebra. Jurnal Riset Pendidikan Matematika, 8(1), 46-60. https://doi.org/10.21831/jrpm.v8i1.40985

\section{INTRODUCTION}

The implementation of mathematics learning expects students to find various ideas they need during the learning process (Yusmanita et al., 2018). That is to construct their ideas into new concepts that can remain stored in students' memories. The implementation of offline learning that has been carried out so far has led students to use the ideas they have to discover new knowledge. Likewise with learning is carried out during this pandemic, where learning is held online. However, lecturers must still design learning to sharpen students' independence and creativity in developing knowledge. Umam and Supiat (2019) revealed that designing meaningful mathematics learning can increase understanding of mathematical concepts. Therefore, mathematics learning that can help fulfill the current situation and conditions in online learning is necessary.

Almost all online learning that happens today involves the internet and uses technological tools such as laptops and smartphones, so learning is strongly influenced by activities designed by lecturers using these technologies. Technology can help develop students' cognitive abilities (Meryansumayeka et al., 2018). Lecturers must be creative in combining learning contents and learning models used in the 
learning process (Sumalasia et al., 2020). With the help of technology, lecturers can direct the learning to remain student-centered, cultivate creativity, and provide opportunities for students to develop their abilities and create innovations. Active involvement in learning plane geometry can help students in cultivating their creativity.

The learning contents learned in the plane geometry course have been learned by students when they were in junior high school and senior high school. The difference is, during lectures, students are more required to understand plane geometry knowledge comprehensively, both conceptual and procedural knowledge, where the concept of plane geometry referred to in this study contains the concepts of points, lines, and two-dimensional shapes or objects. That is intended so that later students who are educated to become prospective teachers can direct learning in geometry material well to their students, both at the junior high school level and at the senior high school level. A good understanding of geometry is needed to reduce problems in learning plane geometry. Hidayati (2014) suggests that there are still problems in learning plane geometry, namely the interconnection between concepts in plane geometry content and abstract content structures causing difficulties in understanding the content. The abstract content structure in plane geometry can be explained using a certain model to visualize geometric concepts to make them easier to understand.

In visualizing geometric concepts into a model, equipment is needed, either manually or using technology. In drawing geometric objects manually, accuracy and precision are needed so that the concepts conveyed are correct. Because drawing geometric objects without using equipment can cause changes in the meaning of the concept, resulting in students having difficulty interpreting geometric objects (Hendroanto \& Fitriyani, 2019). Not all geometric concepts can be well illustrated through manual drawings, but with the help of computers, concepts can be explored to provide learning experiences (Straesser, 2002). The use of computers in learning mathematics needs attention from lecturers, especially in designing learning activities.

Computers as learning media used by lecturers can affect students' understanding of what they are learning. Activities designed by lecturers using media can be used as a form of experience in the learning process so that the concepts learned by students can be remembered in their memory (Saputra et al., 2019). It is necessary to choose a fun learning model to make it easier for students to construct and improve their understanding of concepts (Sutanti et al., 2012). Moreover, in the current state of online learning, students must still be equipped with mastery of technology and have good and correct knowledge of the concept of plane geometry.

Currently, the implementation of learning needs attention so that students have a good understanding of plane geometry. A prototype is needed in the form of a technology-based worksheet in the plane geometry learning process. The current student worksheets are not representative and communicative; as a result, students encounter obstacles and difficulties in interpreting essential concepts in the subject matter (Nurmi et al., 2020) and have not provided students with cognitive experience in building knowledge (Ariawan, 2014). This condition leads to determine the kind of worksheet that is needed in the current learning process.

Worksheets need to (1) help students be critical, responsive, and interactive; (2) provide sufficient space for students to develop creativity and independence; and (3) make students interested in learning mathematics (Ni'mah et al., 2018; Saputri \& Zulkardi, 2019). Learning activities to cultivate students' creativity and independence can be facilitated through the project-based learning (PjBL) model. PjBL can develop students' ability to learn new concepts independently, consciously, and responsibly (Barak, 2012). According to Evans et al. (2018), PjBL is learning that involves a project to guide students to find a solution or generate new knowledge by using the concepts they had. PjBL is defined as authentic learning with student-centered experience by conducting investigations and problem solving to gain knowledge through project activities (King \& Smith, 2020). For learning to be more effective, it is necessary to take steps in PjBL learning. PjBL learning steps as carried out by Azizah and Widjajanti (2019) comprised of: (1) project determination; (2) design of project completion steps; (3) preparation of project implementation schedule; (4) project completion; (5) project preparation and presentation; and (6) evaluation of the project and project results. Conducting learning with the PjBL model can allow students to develop their abilities and improve their learning achievements.

To improve students' learning achievement in plane geometry, lecturers need to conduct activities that can facilitate students to explore all their abilities and independence in finding concepts. Exploration activities can be done with the help of software, namely GeoGebra. GeoGebra software in plane 
geometry learning helps form new concepts and make activities that lead to learning experiences. GeoGebra software can be used to simulate mathematical problems and can be used to explore students' abilities (Amalia et al., 2020; Ismunandar \& Nurafifah, 2018). Research by Nur (2016) showed that GeoGebra could be used as a demonstration medium to provide a visual experience in interacting with mathematical objects. GeoGebra can also be used for feedback in verifying the accuracy of the drawn figure (Nurdin et al., 2019). From the literature study carried out, research on the use of GeoGebra in mathematics learning is more focused on its implementation and effectiveness on learning outcomes. But it has not allowed students to explore the GeoGebra software to form an application that can be used to find concepts in plane geometry course actualized in worksheets. The current need is to produce userfriendly worksheets for the students anywhere, and lecturers can also easily control all student activities that are carried out online.

The developed worksheet refers to the formation of virtual activities that utilize technology. The activities contained in the worksheet are designed with the PjBL learning model. Although the PjBL is often used in face-to-face classrooms, it can be extended to virtual settings using technology via software (Hopper, 2014). Worksheets are developed using software in websites to be easily accessible and designed according to learning needs. Technology can facilitate student-centered pedagogy and collaboration between students, known as project-based learning (Owens \& Hite, 2020). The study results conducted by Branch (2015) revealed that learning the PjBL model with technology when used effectively can improve learning achievement. Learning with the PjBL model in a web-based worksheet also uses GeoGebra to produce GeoGebra applications to form knowledge on plane geometry. GeoGebra provides a learning environment that can facilitate students to work collaboratively in exploring mathematical problems (Takači et al., 2015).

From the description presented before, we can conclude three things that are the focus of the current learning implementation. Firstly, the demands that students need to explore and develop concepts to form new knowledge. Secondly, the need to integrate technology that can help and facilitate students to understand the learning content. Lastly, the activities carried out by students virtually can still be observed and controlled by the lecturer. Accordingly, a web-based worksheet was developed to help lecturers and students in the learning process. Furthermore, learning with the web is very easy to use (Umam \& Supiat, 2019). The web can provide various facilities in learning plane geometry. For this reason, a web-based student worksheet was developed with the PjBL model assisted by GeoGebra on plane geometry. Therefore, this study aims to produce a web-based worksheet with a GeoGebra-assisted $\mathrm{PjBL}$ model that is valid, practical, and effective for basic competencies in the plane geometry course.

\section{METHOD}

This research and development ( $\mathrm{R} \& \mathrm{D}$ ) aimed to produce a usable product in terms of validity, practicality, and effectiveness. Validity refers to the content, construct, and language aspects. Practicality refers to attractiveness and ease of use. Effectiveness refers to the achievement of the desired learning objectives, which is seen from learning achievement. The product is a web-based worksheet with the GeoGebra-assisted PjBL model that undergraduate mathematics education students can use when they learn plane geometry. We applied a 4D (define, design, develop, and disseminate) model to achieve the research objectives (Mulyatiningsih, 2013; Thiagarajan et al., 1974).

The research was conducted from March to April 2021 at the Mathematics Education Study Program, Faculty of Teacher Training and Education, Bengkulu University, involving 34 students who took the plane geometry course in the second semester of the academic year of 2021/2022. The research procedure started with the define stage, namely task analysis, concept analysis, and learning objectives analysis. Those analyses were carried out to find the design of the student worksheet in the plane geometry material so that the products needed by students were obtained. At the design stage, we developed instruments and chose media, formats, and forms of presentation. At the development step, an initial product was assessed by experts, and we conducted product testing. The product testing helped us to determine product quality and improve product parts that needed to revise. In the dissemination stage, the dissemination and implementation of the developed web-based worksheet were carried out.

The research instruments were expert validation sheets used to measure product validity, student response sheets and expert assessment sheets to measure product practicality, tests to measure product effectiveness, and documentation. Table 1 presents the aspects measured for each instrument. 
Jurnal Riset Pendidikan Matematika, 8 (1), 2021 - 49

Effie Efrida Muchlis, Nanang Priatna, Jarnawi Afgani Dahlan

Table 1. Aspects of product validity and practicality assessment

\begin{tabular}{|c|c|}
\hline Type of instruments & Measured aspects \\
\hline Content validation & $\begin{array}{l}\text { The suitability of the material on the student worksheet with basic } \\
\text { competencies and indicators } \\
\text { Problems can be solved with GeoGebra } \\
\text { Using the correct mathematical symbols } \\
\text { Concepts presented in the form of projects } \\
\text { The material presented contains the steps of PjBL }\end{array}$ \\
\hline Construct validation & $\begin{array}{l}\text { Contains identity, basic competencies, and competency achievement indicators } \\
\text { Instructions for using student worksheets } \\
\text { Completion time } \\
\text { Student worksheet design: colors, sizes and fonts, figures are appropriate and } \\
\text { readable }\end{array}$ \\
\hline Language validation & $\begin{array}{l}\text { Spelling based on PUEBI (Pedoman Umum Ejaan Bahasa Indonesia or } \\
\text { General Guideline for Indonesian Spelling System) } \\
\text { The language used is communicative } \\
\text { The information conveyed is clear } \\
\text { Mathematical term consistency }\end{array}$ \\
\hline Student response & $\begin{array}{l}\text { Ease of use } \\
\text { The attraction of the product } \\
\text { Benefits }\end{array}$ \\
\hline Practicality by expert & $\begin{array}{l}\text { Ease of use } \\
\text { The attraction of the product } \\
\text { Benefits }\end{array}$ \\
\hline
\end{tabular}

Validation instruments, student responses, and expert practicality were presented in the form of a questionnaire using a 5-point Likert scale (i.e., $1=$ strongly disagree, $2=$ disagree, $3=$ neither agree nor disagree, $4=$ agree, $5=$ strongly agree). Data of expert validation scores were obtained on a scale of five then converted into qualitative criteria. Calculation of the validation score was done by providing the percentage of assessment based on the following criteria proposed by Hidayat and Irawan (2017).

$$
\text { Validity level }=\frac{\text { Earned score }}{\text { Total score }} \times 100 \%
$$

The interpretation of the expert validation score is as follows.

$$
\begin{aligned}
& 81 \%-100 \% \text { : Very Valid } \\
& 61 \%-80 \%: \text { Valid } \\
& 41 \%-60 \%: \text { :uite Valid } \\
& 21 \%-40 \%: \text { : Less Valid } \\
& 0 \%-20 \%: \text { : Invalid }
\end{aligned}
$$

The validity criteria in this research and development were achieved if the GeoGebra-assisted webbased worksheet at least meets the valid category.

Two experts, lecturers of the Mathematics Education Study Program who are experts in learning media and taught plane geometry course, assessed the practicality of the worksheet. A recommendation column will be given about implementing a web-based worksheet in the plane geometry course on the practicality sheet. The criteria for implementation recommendations are following the research that has been carried out by Ariawan (2014) as follows.

$\mathrm{A}=$ Worksheets can be used without any revision

$\mathrm{B}=$ Worksheets can be used with minor revision

$\mathrm{C}=$ Worksheets can be used with major revision

$\mathrm{D}=$ Worksheets cannot be used

In this research and development, the resulting GeoGebra-assisted web-based worksheet was practical if both experts provide a minimum recommendation on category B (minor revision). In addition to filling in the recommendation column, the experts also filled out an assessment sheet related to implementing the worksheet in the learning process. Students also assessed the practicality of the products developed 
through student response sheets. Furthermore, scores obtained from expert assessment sheets and student response sheets were converted into qualitative form with the following interpretation.

$$
\begin{aligned}
& 81 \%-100 \% \text { : Very practical } \\
& 61 \%-80 \% \text { : Practical } \\
& 41 \%-60 \% \text { : Quite practical } \\
& 21 \%-40 \% \text { : Less practical } \\
& 0 \%-20 \% \text { : Not practical }
\end{aligned}
$$

The GeoGebra-assisted web-based worksheet was said to be practical if the results of expert and student assessments were at least in the practical category.

The data analysis technique uses descriptive methods yet still used quantitative data. Calculation of the worksheet effectiveness was done using final test scores after students engaged in the plane

\begin{tabular}{|c|c|c|}
\hline Content/topic & Indicator & Question level \\
\hline $\begin{array}{l}\text { Congruence of two } \\
\text { triangles }\end{array}$ & $\begin{array}{l}\text { Given two triangles, students are asked to prove that the } \\
\text { two triangles are congruent }\end{array}$ & $\mathrm{C} 2$ \\
\hline $\begin{array}{l}\text { Similarities of two } \\
\text { triangles }\end{array}$ & $\begin{array}{l}\text { Given two triangles, students are asked to prove that the } \\
\text { two triangles are similar }\end{array}$ & $\mathrm{C} 2$ and $\mathrm{C} 3$ \\
\hline Area of a quadrilateral & $\begin{array}{l}\text { Given a quadrilateral figure, students are asked to } \\
\text { determine the area of the quadrilateral when the ratio of } \\
\text { the length of two sides is known }\end{array}$ & $\mathrm{C} 4$ \\
\hline Area of a parallelogram & $\begin{array}{l}\text { Given a parallelogram figure, students are asked to } \\
\text { determine the area of the parallelogram when the length } \\
\text { of the altitude is known }\end{array}$ & $\mathrm{C} 3$ \\
\hline Circle & $\begin{array}{l}\text { Given a figure of three circles that are tangent to each } \\
\text { other, students are asked to determine the length of } \\
\text { rope tied around the three tangent circles. }\end{array}$ & $\mathrm{C} 3$ \\
\hline
\end{tabular}
geometry course using a web-based worksheet with the PjBL model assisted by GeoGebra. The test was conducted for 100 minutes for eight essays (constructed-response) items. The test item indicators are presented in Table 2 .

Table 2. Test item indicators

The conversion of test score results referred to Hidayat and Irawan's (2017) research using the following formula.

$$
S=\frac{R}{N} \times 100
$$

where $S$ is the score of the learning outcomes test, $R$ is the total correct score, and $N$ is the total score of the learning outcomes test.

The score of the learning outcomes test reflects the student's mastery of learning. Students have to obtain a minimum score of $75(\mathrm{~B}+)$ to pass the plane geometry course. The percentage of the student's mastery learning score determined the effectiveness of the web-based worksheet.

$81 \%-100 \%$ : Very effective

$61 \%-80 \%$ : Effective

$41 \%-60 \%$ : Quite effective

$21 \%-40 \%$ : Less effective

$0 \%-20 \%$ : Not effective

The web-based worksheet was said to be effective if the percentage of students who pass the plane geometry course after they participated in learning using a web-based worksheet assisted by GeoGebra is at least at the effective category (i.e., $61 \%$ - $80 \%$ of students pass the course).

\section{RESULTS AND DISCUSSION}

The results of this research and development are presented based on the stages of developing the worksheet with a 4D model. An initial analysis comprised of types of tasks, concepts, and learning objectives analyses was performed at the define stage. Those analyses were begun by looking for 
information about the problems that need to be addressed in learning plane geometry online. Afterward, we analyzed student characteristics, determined the description of worksheet development, and formulated indicators, activities, and skills regarding tasks required by students to achieve learning objectives. In the define stage, we analyzed the learning model and research objectives, developed SAP (Satuan Acara Perkuliahan or course plan), and developed learning outcomes test instruments. The activities conducted at the define stage aimed to formulate a connection between design development and learning objectives in producing web-based worksheets on plane geometry.

At the design stage, a worksheet was constructed to make students active, creative, and independent during the learning process in discovering and exploring the concept of plane geometry. The worksheet was designed on the web www.geometri.effie.info using the PjBL model assisted by GeoGebra software. PjBL model was applied to focus on the existence of products as a form of process in finding concepts. Students discovered the concept by carrying out exploration activities that produce an application with the help of GeoGebra.

We developed web-based worksheets on plane geometry for four meetings and one meeting for formative tests. The first to fourth meetings discussed the concepts of similarity and congruence of triangles, perimeter and area of quadrilaterals and triangles, circle elements, and common internal and external tangents, respectively. Lastly, in the fifth meeting, we carried out a learning outcomes test. To make it easier to develop a design format of worksheets on the web, we began by constructing a storyboard. The blueprint or worksheet model can be shown from the constructed storyboard. The initial design of a web-based worksheet is presented in Figure 1 to Figure 4.

\section{Description:}

The main page on the web

Component: (1) title of worksheet; (2) developer name; (3) log in form

Display: see Figure 1

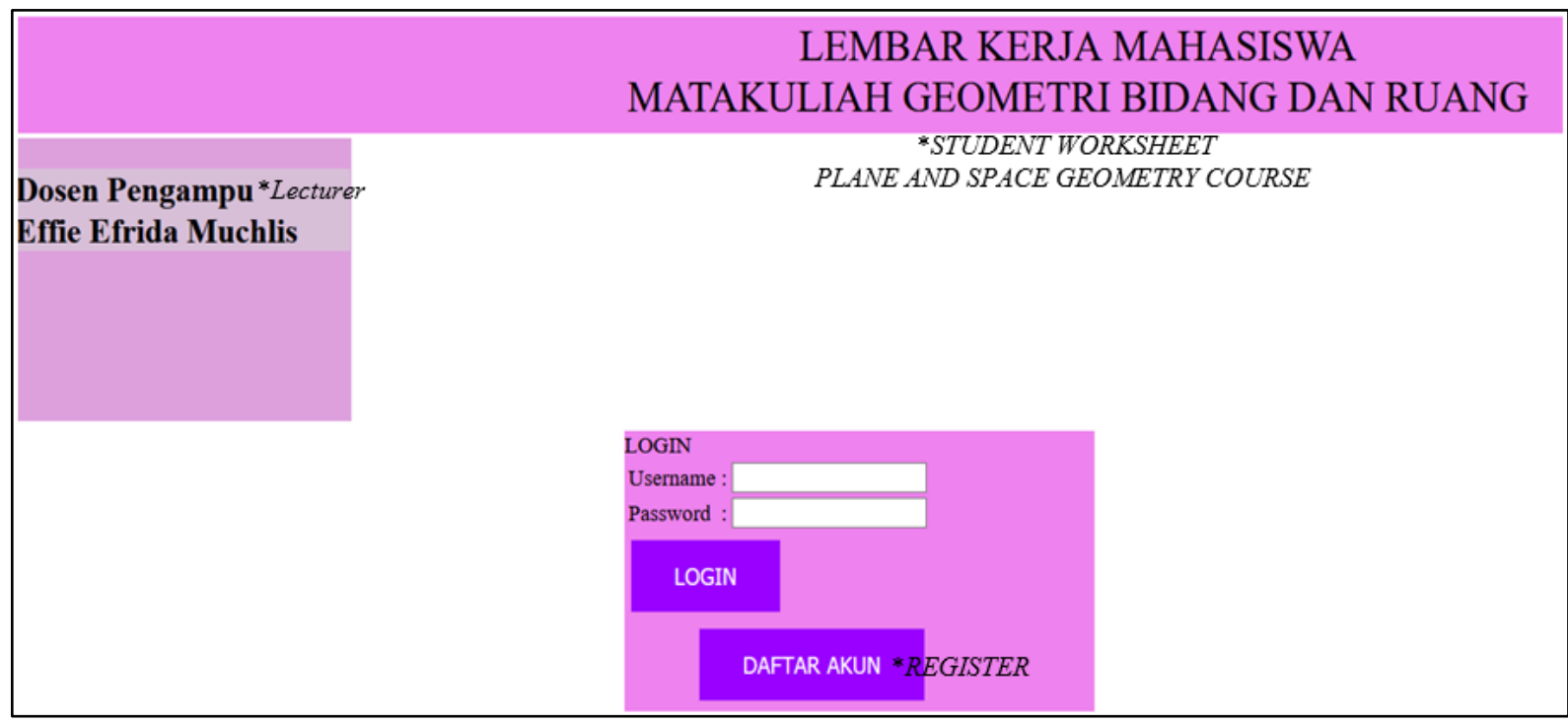

Figure 1. The main page on the web (Note. * translation)

\section{Description:}

Student worksheet manual page: Explain how to use a web-based worksheet Component: (1) syllabus; (2) video how to use GeoGebra online; (3) rules for conducting evaluation Display: see Figure 2 
Jurnal Riset Pendidikan Matematika, 8 (1), 2021 - 52

Effie Efrida Muchlis, Nanang Priatna, Jarnawi Afgani Dahlan

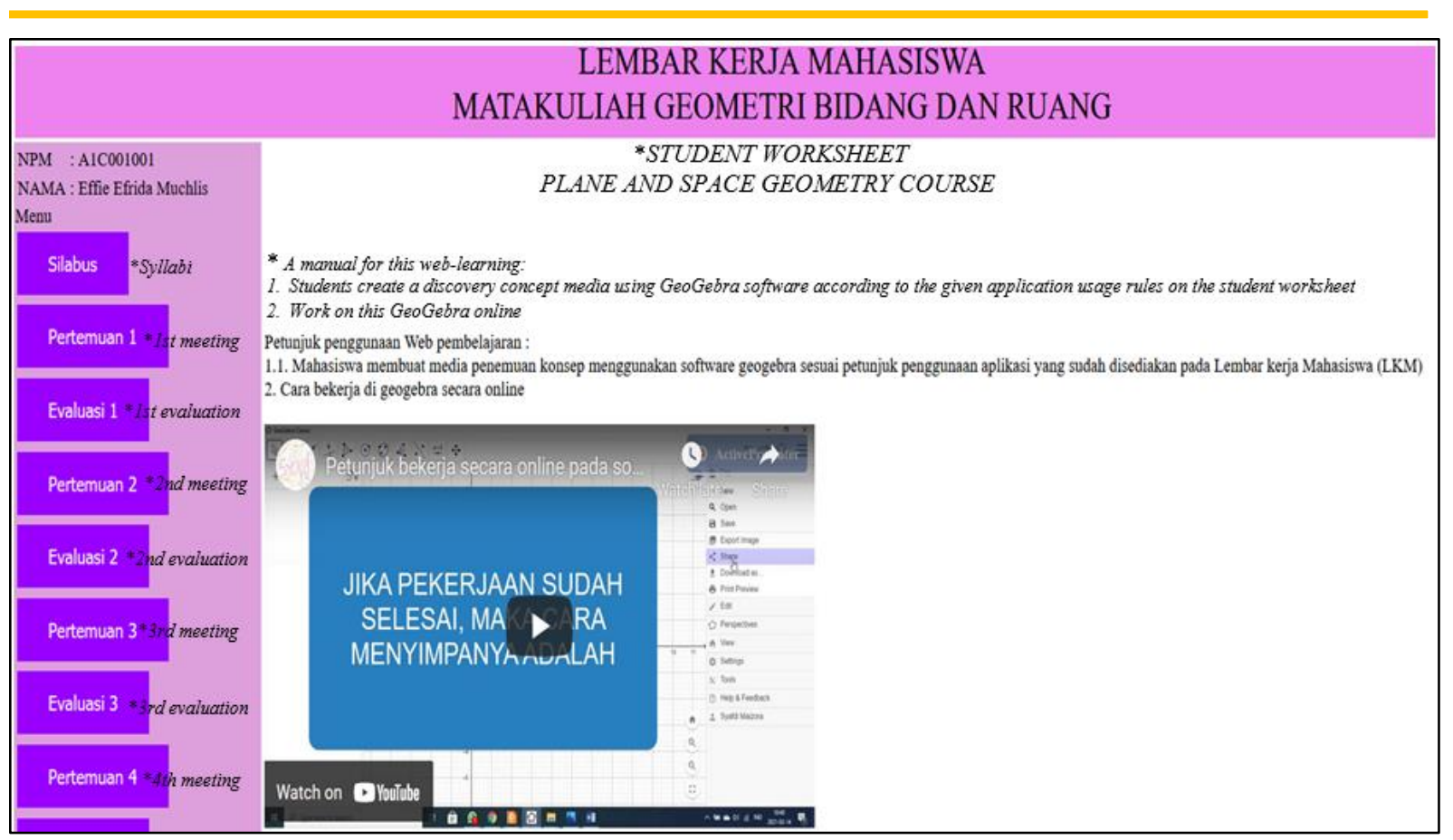

Figure 2. Student worksheet manual page (Note. * translation)

\section{Description:}

Worksheet page: The worksheet page contains working steps to obtain the following concepts: (a) congruence and similarity of triangles; (b) area of quadrilateral and triangle; (c) elements of circle; and (d) common internal and external tangents

Component: (1) the premise of creating the GeoGebra application; (2) application link that has been created; (3) data analysis; (4) conclusion; and (5) sample questions.

Display: see Figure 3

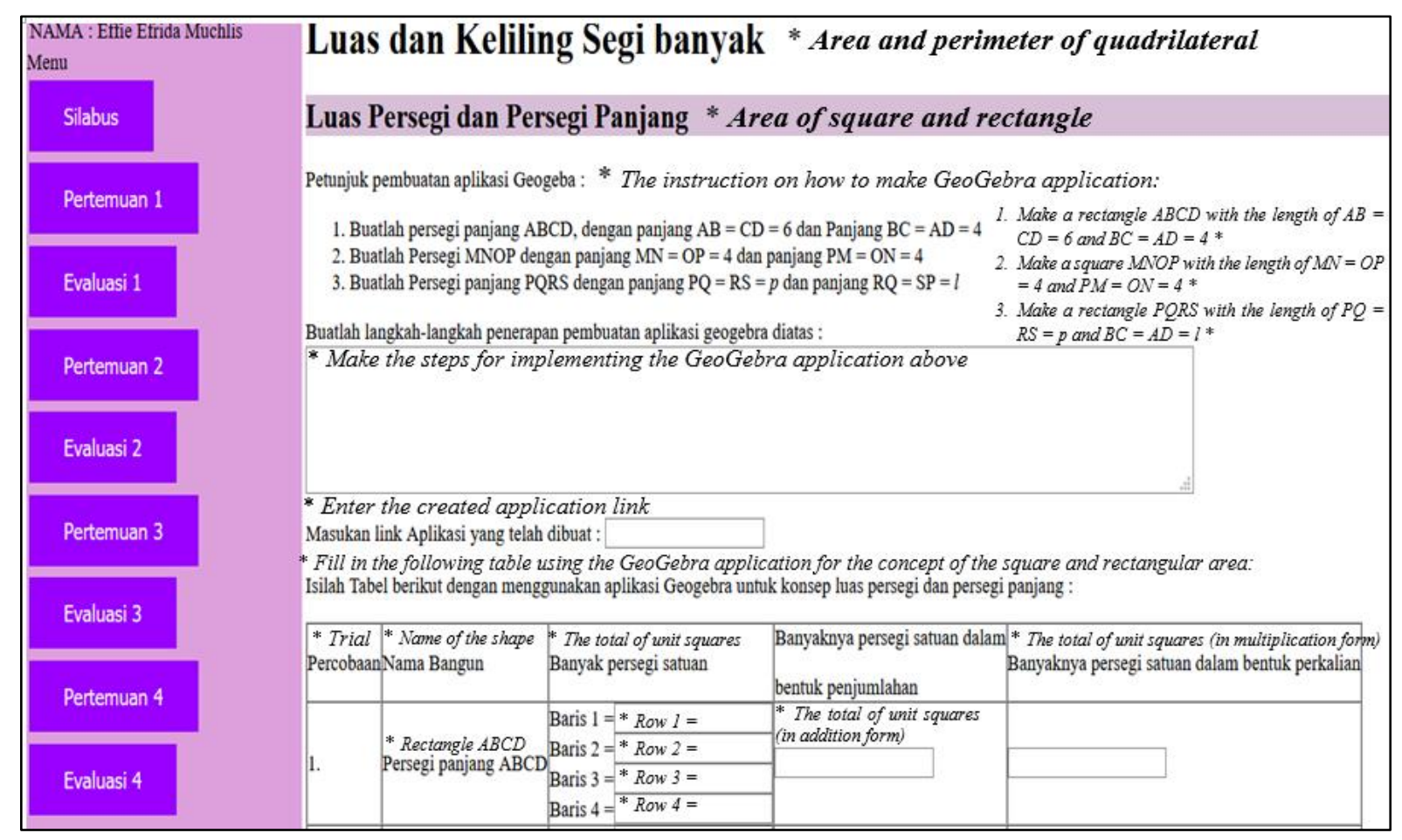

Figure 3. Worksheet page (Note. * translation) 


\section{Description:}

Evaluation page: Each student worksheet is equipped with an evaluation and a final test Component: (1) evaluation; (2) final test

Display: see Figure 4

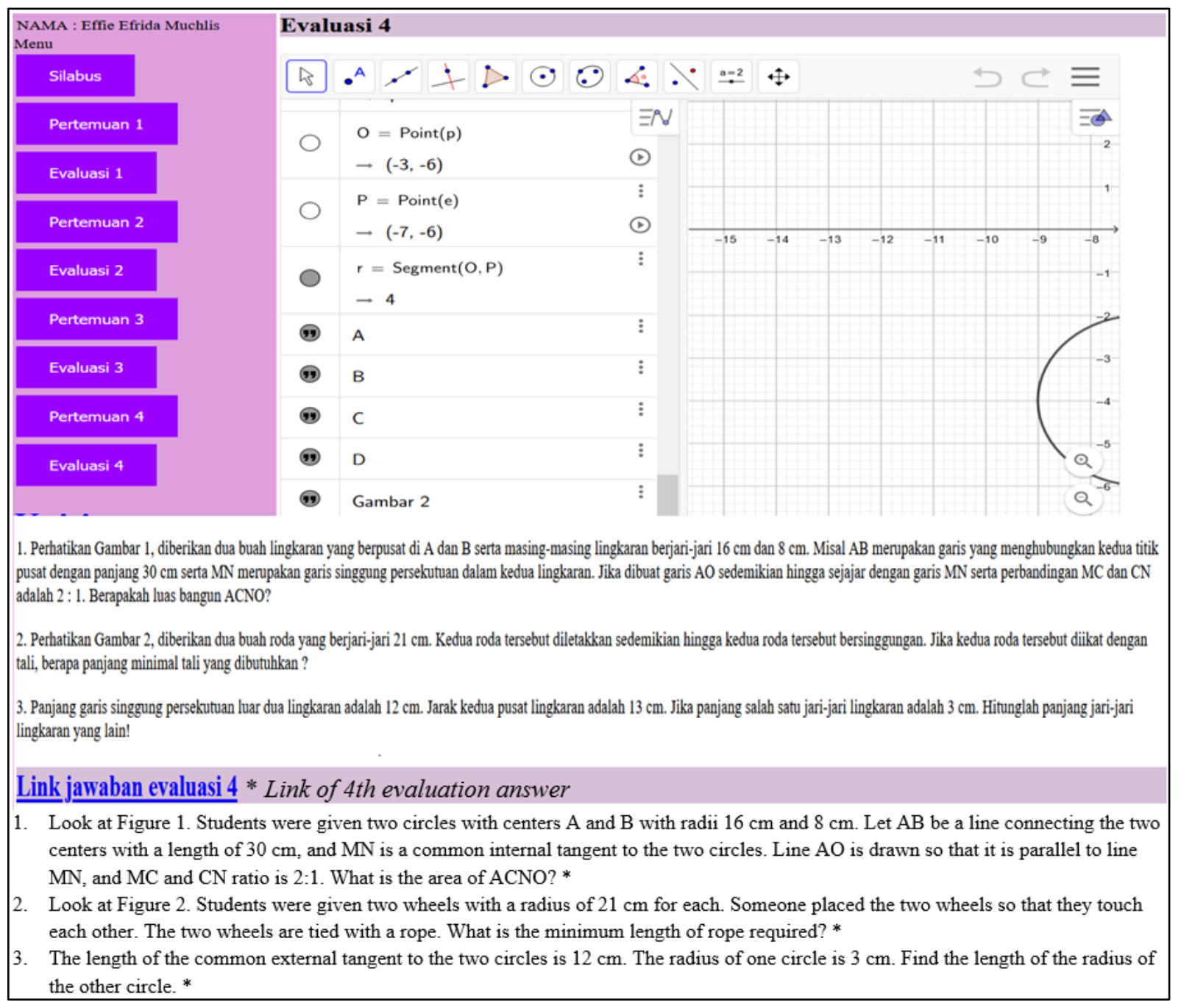

Figure 4. Evaluation page (Note. * translation)

The appearance of the web-based worksheet pages for each material or topic is the same as a whole, consisting of several pages with buttons to continue to the next page or return to the previous page. Web-based worksheets can be opened using various devices, including laptops, tablets, or smartphones. Learning began with synchronous meetings using Zoom to explain activities and the final product to discover concepts. The worksheets were worked on a web page and using GeoGebra software. The lecturer could control all answers made by students on their web page because every answer on the worksheet was already stored in a database equipped with the time of completion and the time students access it. Completing worksheets requires the help of GeoGebra software which could be accessed online. That was intended so that each student has a separate account. Using GeoGebra online can also prevent students from plagiarizing when exploring concepts using GeoGebra software. After all webbased worksheet pages have been created, proceed with the development stage, which aims to realize the design and assess the product's validity, practicality, and effectiveness.

At the worksheet development, the product was validated by two lecturers of the Mathematics Education Study Program at Bengkulu University and one lecturer who currently takes Mathematics Education Doctoral Program. The validation is oriented by the PjBL model assisted by GeoGebra. The worksheet that the validator has given input was then revised. The validity of the web-based worksheet with the PjBL model assisted by GeoGebra refers to three aspects (i.e., content, construction, and language) (Zulkardi, 2006). The comments and suggestions obtained from the results of expert 
validation are as follows. Firstly, for the construction aspect, the result of the web-based worksheet is concordant with the PjBL model. It is worth noting that the instructions for creating the GeoGebra application do not need to be sequentially delivered so that students can explore making GeoGebra applications independently and innovatively. Secondly, for the content aspect, the results of validation by content experts showed that the content contained in the web-based worksheet is relevant to basic competencies. It is merely learning indicators that need to be consistent in using mathematical symbols on each web page and the addition of sample questions on worksheet 1 and worksheet 2 . Thirdly, for the language aspect, the results of validation indicated that a web-based worksheet that has been developed relevant to the Indonesian language rules. It was just that some figures required additional explanation. According to the experts' suggestions and recommendations, further improvements were made to the web-based worksheet.

The results of calculating the validation score obtained a percentage of $89.1 \%$. Based on the validation criteria used, this percentage indicates that the three validators stated that the web-based worksheet with the GeoGebra-assisted PjBL model is in the very valid category. Validation by experts from the content aspect shows that the material contained in the web-based student worksheet is following the basic competencies and learning indicators. In addition, the concept discovery steps inside the worksheet have also used GeoGebra software as the product produced to find concepts. From the language aspect, the validation results revealed that students could discover concepts using the directions and instructions on the worksheet because it uses easy-to-understand language. The results of language validation explained that the student worksheet had met the grammatical suitability, and the sentences do not cause double interpretation. In terms of construction, it is explained that the student worksheet is following the PjBL model and has included exploration activities using GeoGebra in using the worksheet. However, it still had some parts that needed to be fixed according to the validators' suggestions. A draft 2 of the worksheet was produced based on the validation results obtained at the development stage. The resulting second draft was then used to test the practicality of the developed product.

The practicality of the web-based worksheet was obtained based on the assessment of two experts and trials to students in plane geometry lectures. Practicality questionnaires assessed by students and experts were used to determine whether the developed web-based worksheet can help students understand the content. The results of the assessment sheets by students and experts are presented in Table 3.

Table 3. Web-based worksheet practicality assessment results

\begin{tabular}{lc}
\hline Assessor & $\begin{array}{c}\text { Practicality } \\
\text { percentage }\end{array}$ \\
\hline Expert 1 & $100 \%$ \\
Expert 2 & $100 \%$ \\
Student & $84,4 \%$ \\
Mean & $94,8 \%$ \\
\hline
\end{tabular}

Table 3 shows that the practicality of the developed web-based worksheet is at a score of $94.8 \%$. The results of the assessment indicate that the product is in the very practical category. The interpretation of the results of the practicality assessment by students showed that the web-based worksheet could be used without revision. Meanwhile, experts' interpretation of the assessment results showed that the webbased worksheet could also be used without revision. In general, the results of the practicality assessment showed that the developed web-based worksheet is easy to use and attractive.

Assessment of the effectiveness of the web-based worksheet was carried out through the results of the learning outcomes test, in which 34 students were involved. The descriptive statistics of the test results are presented in Table 4. Based on the test results, the percentage of learning mastery was $73.53 \%$ which meets the effective criteria. That means that a web-based worksheet with the PjBL model assisted by GeoGebra effectively facilitates students' understanding of the learning material or content through online learning on plane geometry. The research results indicated that the developed web-based worksheet with the PjBL model assisted by GeoGebra could support student online learning activities and learning outcomes on plane geometry. 
Jurnal Riset Pendidikan Matematika, 8 (1), 2021 - 55

Effie Efrida Muchlis, Nanang Priatna, Jarnawi Afgani Dahlan

Table 4. Descriptive statistic of test result

\begin{tabular}{lc}
\hline Description & Score \\
\hline Mean & 80.09 \\
Standard deviation & 16.04 \\
Maximum value & 100 \\
Minimum value & 30 \\
\hline
\end{tabular}

The implementation of the web-based worksheet in plane geometry lecture at the Mathematics Education Study Program, Faculty of Teacher Training and Education, Bengkulu University, was done at the dissemination stage. In this lecture activity, the worksheet was used to facilitate students to develop their creativity and innovation in constructing knowledge. In addition, the worksheet was also promoted on social media as a technology-based learning media that can be easily accessed. The developed product can be accessed using a username which can be obtained by contacting the developer.

\section{Discussion}

The developed worksheet has met the valid and effective criteria, which can be observed during the learning process. Students become more independent and produce various forms of geometric applications to find concepts related to plane geometry. The results show that students are motivated to be actively involved in learning, as Nuraeni et al. (2021) expressed that learning with the help of GeoGebra has motivated students to learn more independently. Student independence can be trained by familiarizing students with making plans and realizing them according to the planned time. These activities can be carried out in learning with the PjBL model. In PjBL, the first step is to determine the project (Azizah \& Widjajanti, 2019). Independence and responsibility are needed to produce a product of a project optimally. The project is the final product of the learning process, which is the application of GeoGebra on the plane geometry. The application directs students to use the data included in GeoGebra during generalizing concepts. In addition, students can also connect objects that they have made on GeoGebra when solving the given various problems. The GeoGebra application as a learning product will provide a learning experience for students.

Experience in learning using GeoGebra will return good results if it is developed with activities that provide opportunities for students to explore the software independently. This result supports research conducted by Arbain and Shukor (2015). They summarized that using technology tools can increase students' interest in finding new things caused by their interest in technology, so the mathematics learning outcomes using GeoGebra are better. The use of GeoGebra allows the creation of an effective learning environment for examining work-related figures and graphics (Kovács et al., 2020). Geometry requires illustrations to make it easier for students to observe and identify them to build concepts (Nugroho, 2019). Through GeoGebra, students analyze data to conclude the concept. Figure 5 demonstrates the examples of applications produced by students, followed by analysis and concepts found.

Web-based worksheets support online learning using the PjBL model. Students' online learning activities using web-based the worksheet with the PjBL model are more structured and observed by lecturers. The students already know what activities to do, what products to produce, and what concepts to find, which is to produce an understanding of the concept of plane geometry. According to the results of research by Astuti and Wijaya (2021), PjBL can support students in building a deeper understanding of a mathematical concept. The worksheet is also observable because the project uses the web to observe all virtual student activities on the worksheet through the database. The products produced by students in learning plane geometry using the web-based worksheet were reflected to produce a better GeoGebra application product. Although students work individually, students still interact synchronously to collaborate in virtual classes, improve the products produced, and be responsible for the products and concepts produced. According to research conducted by Takači et al. (2015), through the construction of knowledge in an individual setting, students can explain their ideas and realize them in the learning environment. 
Jurnal Riset Pendidikan Matematika, 8 (1), 2021 - 56

Effie Efrida Muchlis, Nanang Priatna, Jarnawi Afgani Dahlan

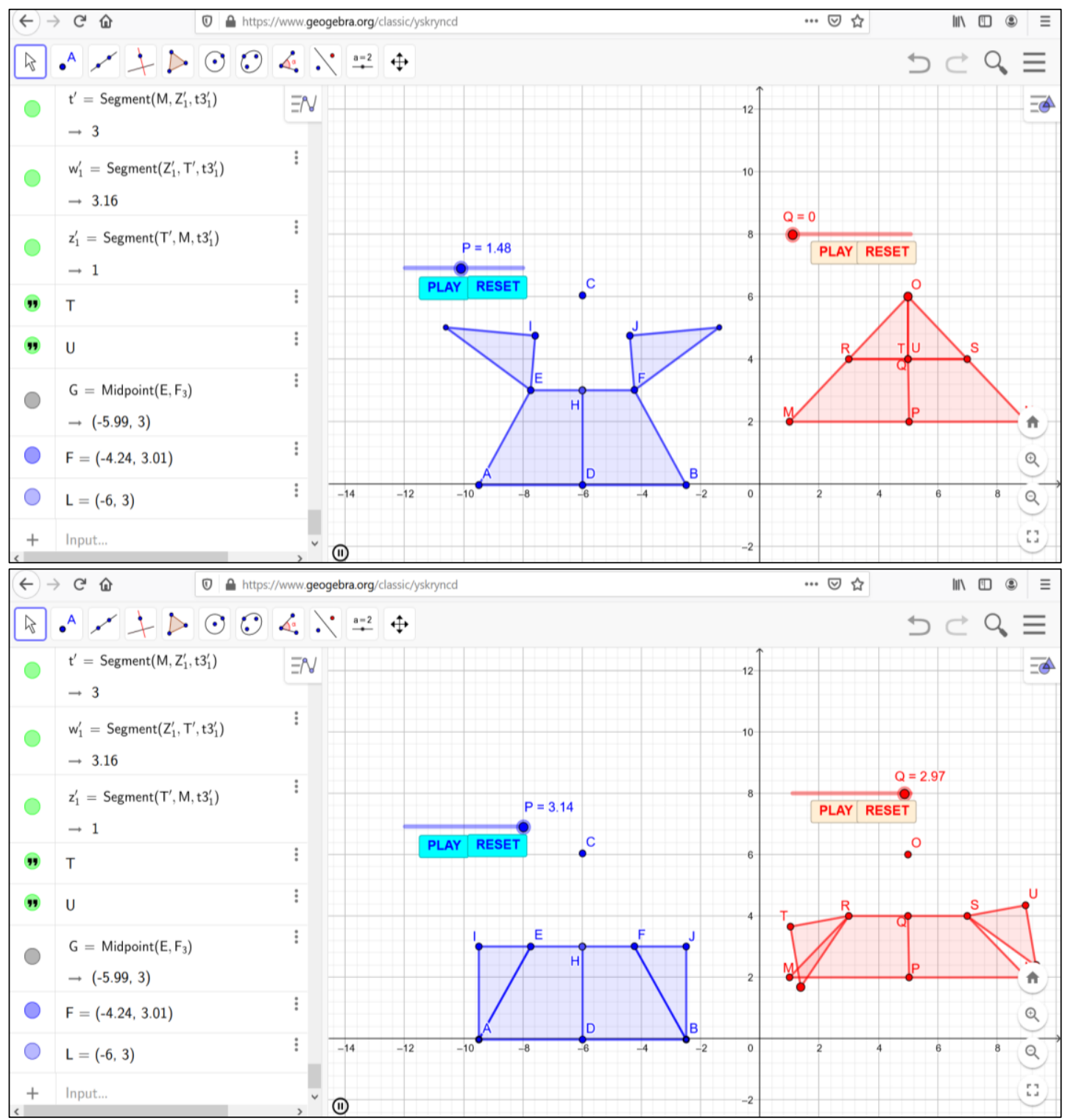

Figure 5. Examples of GeoGebra products for the concept of area of a triangle

The developed product and experience in online learning made learning geometry using a webbased worksheet effective. Students can develop creativity and practice thinking skills through the worksheets to use the obtained data to find new concepts in the plane geometry content. Those in line with the research conducted by Samo (2017) that suggested students must be facilitated to solve complex problems involving thinking skills and developing them in higher education. Students still have to develop thinking skills even in online learning. Developing thinking skills in online learning on plane geometry can be executed by not monotonous and involves activities that attract interest and attention to learning. That agrees with Nurdin et al. (2019), who stated that planning abstract mathematics learning in more concrete, not monotonous, and attractive can build a good understanding of the learning content.

Understanding geometry content can be seen from the mastery of learning, online learning activities, and student responses during learning. Students were looking active in creating GeoGebra applications, reflected in various GeoGebra applications produced in finding concepts. Students were enthusiastic about improving the GeoGebra application during the discussion process, analyzing the data on GeoGebra to find concepts, and connecting the data obtained with the knowledge they already had to construct new knowledge. In line with the research results conducted by Sari (2016), student understanding will be deeper when students can link concepts they already have with new concepts they will learn. 
The developed student worksheet has characteristics or advantages that include several things. Firstly, the worksheet contains learning using the PjBL model that produces products to get new concepts. Secondly, the worksheets can be used as an alternative to online learning media. Because it is accessed online, all virtual activities can be controlled and directed by lecturers through database observations. Lastly, the use of worksheets assisted by GeoGebra provides opportunities for students to conduct exploration, which results in GeoGebra applications in training students' independence and creativity. With these characteristics, it is hoped that the products produced in this study can create a meaningful learning process, even though the learning is carried out online. A meaningful learning process will positively impact the development of student abilities (Sudarwan \& Retnawati, 2015).

Even though this research has produced a product of a web-based worksheet proven to be valid, practical, and effective, this study still has some limitations. One of the limitations is that the developed product has not been tested on a wider scale yet. Hence, further research is demanded through experimental research and involving a representative sample to test the effectiveness of the products. Moreover, for further research, the development of a similar student worksheet can be implemented additionally on other geometry topics.

\section{CONCLUSION}

This research and development produced a web-based worksheet with a PjBL model assisted by GeoGebra that was valid in content, construction, and language aspects. Based on the assessments of experts and students, the learning process using a web-based worksheet with the PjBL model assisted by GeoGebra was practical. The results indicate that the developed product is easy to use and attractive. The worksheet was also declared effective based on the learning outcomes test results. That shows the developed product can assist students in learning the content in the plane geometry course. Furthermore, to test the effectiveness of the worksheet developed, it is necessary to conduct a trial using an experimental research design. This test is expected to improve the quality of the developed products to improve other mathematical abilities corresponding to higher education curriculum standards.

\section{REFERENCES}

Amalia, S. R., Purwaningsih, D., Nur, A., Widodo, A., \& Fasha, E. F. (2020). Model problem based learning berbantuan GeoGebra dan model realistic mathematics education terhadap representasi matematis siswa ditinjau dari gaya kognitif [Problem-based learning model assisted by GeoGebra and realistic mathematics education model on students' mathematical representation viewed from cognitive style]. Jurnal Elemen, 6(2), 157-166. https://doi.org/10.29408/jel.v6i2.1692

Arbain, N., \& Shukor, N. A. (2015). The effects of GeoGebra on students achievement. Procedia Social and Behavioral Sciences, 172, 208-214. https://doi.org/10.1016/j.sbspro.2015.01.356

Ariawan, I. P. W. (2014). Pengembangan LKM multi representasi berbantuan GeoGebra untuk meningkatkan kemampuan berpikir kritis mahasiswa [Development of multi-representation LKM assisted by GeoGebra to improve students' critical thinking skills]. JPI (Jurnal Pendidikan Indonesia), 3(1), 359-371. https://doi.org/10.23887/jpi-undiksha.v3i1.2918

Astuti, W., \& Wijaya, A. (2021). Learning trajectory berbasis proyek pada materi definisi himpunan [Project-based learning trajectory on the definition of set material]. Jurnal Riset Pendidikan Matematika, 7(2), 254-266. https://doi.org/10.21831/jrpm.v7i2.16483

Azizah, I. N., \& Widjajanti, D. B. (2019). Keefektifan pembelajaran berbasis proyek ditinjau dari prestasi belajar, kemampuan berpikir kritis, dan kepercayaan diri siswa [The effectiveness of project-based learning viewed from students' learning achievement, critical thinking skill, and self-confidence]. Jurnal Riset Pendidikan Matematika, 6(2), 233-243. https://doi.org/10.21831/jrpm.v6i2.15927

Barak, M. (2012). From "doing" to "doing with learning": Reflection on an effort to promote selfregulated learning in technological projects in high school. European Journal of Engineering Education, 37(1), 105-116. https://doi.org/10.1080/03043797.2012.658759

Branch, L. J. (2015). The impact of project-based learning and technology on student achievement in mathematics. In W. W. K. Ma, A. H. K. Yuen, J. Park, W. W. F. Lau, \& L. Deng (Eds.), New media, 
knowledge practices and multiliteracies (pp. 259-268). Springer. https://doi.org/10.1007/978-981287-209-8

Evans, R., Friedman, J., McGrath, L., Myers, P., \& Ruiz, A. (2018). Math path: Encouraging female students in mathematics through project-based learning. Primus: Problems, Resources, and Issues in Mathematics Undergraduate Studies, 28(4), 287-299. https://doi.org/10.1080/10511970.2017.1339154

Hendroanto, A., \& Fitriyani, H. (2019). Pengembangan alat pembelajaran GeoKlik untuk pembelajaran geometri [The development of the learning tool "GeoKlik" for geometry learning]. Pythagoras: Jurnal Pendidikan Matematika, 14(1), 102-111. https://doi.org/10.21831/pg.v14i1.22063

Hidayat, A., \& Irawan, I. (2017). Pengembangan LKS berbasis RME dengan pendekatan problem solving untuk memfasilitasi kemampuan pemecahan masalah matematis siswa [The development of RME-based worksheets with a problem-solving approach to facilitate students' mathematical problem-solving skills]. Jurnal Cendekia: Jurnal Pendidikan Matematika, 1(2), 51-63. https://doi.org/10.31004/cendekia.v1i2.20

Hidayati, V. O. (2014). Peningkatan pembelajaran bangun datar melalui media puzzle pada siswa sekolah dasar [The improvement of flat plane figure learning through puzzle media for elementary school students]. Journal of Elementary Education, 3(4), 14-20. https://journal.unnes.ac.id/sju/index.php/jee/article/view/3658

Hopper, S. B. (2014). Bringing the world to the classroom through videoconferencing and project-based learning. TechTrends, 58(3), 78-89. https://doi.org/10.1007/s11528-014-0755-4

Ismunandar, D., \& Nurafifah, L. (2018). Efektivitas penggunaan buku ajar berbantuan GeoGebra untuk mencapai ketuntasan hasil belajar matematis [The effectiveness of using GeoGebra-assisted textbooks to achieve completeness mathematical learning outcomes]. Dialektika, 5(2), 70-85. https://journal.peradaban.ac.id/index.php/jdpmat/article/view/340

King, B., \& Smith, C. (2020). Using project-based learning to develop teachers for leadership. The Clearing House: A Journal of Educational Strategies, Issues and Ideas, 93(3), 158-164. https://doi.org/10.1080/00098655.2020.1735289

Kovács, Z., Recio, T., \& Vélez, M. P. (2020). Reasoning about linkages with dynamic geometry. Journal of Symbolic Computation, 97, 16-30. https://doi.org/10.1016/j.jsc.2018.12.003

Meryansumayeka, M., Yusuf, M., \& Suganda, V. A. (2018). Pengembangan video pembelajaran berbasis PMRI untuk mendukung mental calculation siswa dalam permasalahan aritmetika sosial [Development of PMRI-based learning videos to support students' mental calculations in social arithmetic problems]. Jurnal Elemen, 4(2), 119--130. https://doi.org/10.29408/jel.v4i2.634

Mulyatiningsih, E. (2013). Metode penelitian terapan bidang pendidikan [Applied research methods in education]. UNY Press

Ni'mah, S., Lestari, N. C., \& Adawiyah, R. (2018). Pengembangan dan uji validasi perangkat pembelajaran SMA berbasis Kurikulum 2013 pada konsep sistem pencernaan [Development and validation of high school learning devices based on Curriculum 2013 on the digestive system concept]. Jurnal Pendidikan Hayati, 4(1), 22-30. https://jurnal.stkipbjm.ac.id/index.php/JPH/article/view/446/239

Nugroho, D. A. (2019). Pengembangan perangkat pembelajaran geometri dengan mengadaptasi model CORE untuk meningkatkan efikasi diri [The development of geometry learning kits adapted from CORE model to improve self-efficacy]. Jurnal Riset Pendidikan Matematika, 6(1), 39-52. https://doi.org/10.21831/jrpm.v6i1.11599

Nur, I. M. (2016). Pemanfaatan program GeoGebra dalam pembelajaran matematika [The use of the GeoGebra program in learning mathematics]. Delta-Pi: Jurnal Matematika dan Pendidikan Matematika, 5(1), 10-19. http://dx.doi.org/10.33387/dpi.v5i1.236

Nuraeni, Z., Indaryanti, I., \& Sukmaningthias, N. (2021). Pengembangan perangkat pembelajaran bercirikan CTL berbantuan GeoGebra menggunakan model flipped learning [Development of 
learning kits characterized by GeoGebra-assisted CTL using a flipped learning model]. Jurnal Elemen, 7(1), 56-67. https://doi.org/10.29408/jel.v7i1.2723

Nurdin, E., Ma'aruf, A., Amir, Z., Risnawati, R., Noviarni, N., \& Azmi, M. P. (2019). Pemanfaatan video pembelajaran berbasis GeoGebra untuk meningkatkan kemampuan pemahaman konsep matematis siswa SMK [The use of learning video-based GeoGebra to improve students' ability in understanding mathematical concepts]. Jurnal Riset Pendidikan Matematika, 6(1), 87-98. https://doi.org/10.21831/jrpm.v6i1.18421

Nurmi, N., Yunita, A., Yusri, R., \& Delyana, H. (2020). Efektivitas penggunaan lembar kerja mahasiswa berbasis project based learning (PjBL) terintegrasi ICT [Effective use of ICT-integrated projectbased learning (PjBL) student worksheets]. Aksioma: Jurnal Program Studi Pendidikan Matematika, 9(4), 1018-1025. https://doi.org/10.24127/ajpm.v9i4.3190\%0A

Owens, A. D., \& Hite, R. L. (2020). Enhancing student communication competencies in STEM using virtual global collaboration project-based learning. Research in Science and Technological Education, 39(3), 1-27. https://doi.org/10.1080/02635143.2020.1778663

Samo, D. D. (2017). Kemampuan pemecahan masalah matematika mahasiswa tahun pertama dalam memecahkan masalah geometri konteks budaya [Mathematical problem-solving ability of firstyear university students in solving geometric problems of cultural context]. Jurnal Riset Pendidikan Matematika, 4(2), 141-152. https://doi.org/10.21831/jrpm.v4i2.13470

Saputra, R., Thalia, S., \& Gustiningsi, T. (2019). Pengembangan media pembelajaran berbasis komputer dengan adobe flash pro cs6 pada materi luas bangun datar [The development of computer-based learning media with adobe flash pro cs6 on the area of flat shape material]. Jurnal Pendidikan Matematika, 14(1), 67-80. https://doi.org/10.22342/jpm.14.1.6794.67-80

Saputri, N. W., \& Zulkardi, Z. (2019). Pengembangan LKPD pemodelan matematika siswa SMP menggunakan konteks ojek online [The development of LKPD mathematical modeling for junior high school students using the context of online motorcycle taxis/ojek]. Jurnal Pendidikan Matematika, 14(1), 1-14. https://doi.org/10.22342/jpm.14.1.6825.1-14

Sari, W. R. (2016). Pengembangan perangkat pembelajaran bangun ruang di SMP dengan pendekatan pendidikan matematika realistik [Developing space learning kit in junior high school with realistic mathematics education approach]. Jurnal Riset Pendidikan Matematika, 3(1), 109-121. https://doi.org/10.21831/jrpm.v3i1.10407

Straesser, R. (2002). Cabri-géomètre: Does dynamic geometry software (DGS) change geometry and its teaching and learning? International Journal of Computers for Mathematical Learning, 6(3), 319-333. https://doi.org/10.1023/A:1013361712895

Sudarwan, R. E., \& Retnawati, H. (2015). Pengembangan perangkat assessement pembelajaran matematika pokok bahasan geometri dan pengukuran SMP/MTs [Developing mathematic assessment product of learning geometric and measuring for students junior high school]. Jurnal Riset Pendidikan Matematika, 2(2), 251-261. https://doi.org/10.21831/jrpm.v2i2.7344

Sumalasia, I. K. Y., Suarsana, I. M., \& Astawa, I. W. P. (2020). Pengembangan bahan ajar interaktif multi representasi pada materi geometri kelas VII SMPLB Tunarungu [Development of interactive multi-representational teaching material on geometry topic for 7th-grade hearingimpaired students of special junior high school]. Pythagoras: Jurnal Pendidikan Matematika, 15(1), 36-47. https://doi.org/10.21831/pg.v15i1.25851

Sutanti, S., Istiyati, S., \& Djaelani, D. (2012). Peningkatan pemahaman konsep luas bangun datar melalui model pembelajaran kooperatif STAD [The improvement of concept understanding of flat shapes area through the STAD cooperative learning model]. Didaktika Dwija Indria, 2(1), 16. https://jurnal.fkip.uns.ac.id/index.php/pgsdsolo/article/view/182

Takači, D., Stankov, G., \& Milanovic, I. (2015). Efficiency of learning environment using GeoGebra when calculus contents are learned in collaborative groups. Computers and Education, 82, 421431. https://doi.org/10.1016/j.compedu.2014.12.002 
Jurnal Riset Pendidikan Matematika, 8 (1), 2021 - 60

Effie Efrida Muchlis, Nanang Priatna, Jarnawi Afgani Dahlan

Thiagarajan, S., Semmel, D. S., \& Semmel, M. I. (1974). Instructional development for training teachers of exceptional children: A sourcebook. Centre for Innovation in Teaching the Handicapped.

Umam, K., \& Supiat, S. (2019). Pengaruh pembelajaran kooperatif tipe STAD dengan bantuan website terhadap kemampuan pemahaman konsep geometri siswa kelas VIII [The effect of STAD type cooperative learning integrated with the website on the ability to understand the geometry concepts of class VIII students]. Jurnal Elemen, 5(2), 170. https://doi.org/10.29408/jel.v5i2.1297

Yusmanita, S., Ikhsan, M., \& Zubainur, C. M. (2018). Penerapan pendekatan matematika realistik untuk meningkatkan kemampuan operasi hitung perkalian [The implementation of a realistic mathematical approach to improving the ability of multiplication arithmetic operations]. Jurnal Elemen, 4(1), 93. https://doi.org/10.29408/jel.v4i1.469

Zulkardi, Z. (2006). Formative evaluation: What, why, when and how. http://www.oocities.org/zulkardi/books.html 